\title{
Hydrogen sulfide alleviates chlorobenzene toxicity in soybean seedlings
}

\author{
Sulfeto de hidrogênio e clorobenzeno na toxicidade da soja
}

\author{
Jin Feng Chen ${ }^{\mathrm{I}, \text { II }^{*}}$ Chan Jiao
}

\section{ABSTRACT}

As a gas signaling molecule, endogenous hydrogen sulfide $\left(H_{2} S\right)$ plays a crucial role in the plant stress response. However, the role of $H_{2} S$ in the response to organic pollutants specifically has not been studied. Here, the effects of $\mathrm{H}_{2} \mathrm{~S}$ addition on soybean (Glycine max) seedlings tolerance of 1,4-Dichlorobenzene (1,4-DCB) were investigated. Under 1,4$D C B$ stress, the growth of soybean seedlings roots and stems was inhibited, while L-/D-cysteine desulfhydrase ( $L C D / D C D)$ activity was induced and endogenous $H_{2} S$ increased. When applied jointly with sodium hydrosulfide (NaHS), a $\mathrm{H}_{2} \mathrm{~S}$ donor, root growth inhibition was effectively alleviated. Pre-treatment of seedlings with $0.4 \mathrm{mmol} \mathrm{L}^{-1} \mathrm{NaHS}$ reduced the malondialdehyde (MDA) and reactived oxygen species (ROS) content, mitigating root cell toxicity significantly. Further experiments confirmed that NaHS enhanced soybean seedlings peroxidase (POD) and superoxide dismutase (SOD) enzyme activities. In contrast, these effects were reversed by hypotaurine (HT), a $\mathrm{H}_{2} \mathrm{~S}$ scavenger. Therefore, $\mathrm{H}_{2} \mathrm{~S}$ alleviated 1,4-DCB toxicity in soybean seedlings by regulating antioxidant enzyme activity to reduce cell oxidative damage.

Key words: hydrogen sulfide $\left(H_{2} S\right)$, soybean seedlings, 1,4 dichlorobenzene (1,4-DCB), toxicity, oxidative stress.

\section{RESUMO}

Tal como uma molécula de sinal de gás, sulfureto de hidrogenio endógena $\left(\mathrm{H}_{2} \mathrm{~S}\right)$ desempenha um papel crucial na resposta ao stress das plantas. Mas não foi relatado o papel de $H 2 S$ em plantas poluentes orgânicos stress. Este estudo sobre a variação de $H 2 S$ envolvido em plântulas de soja tolerância 1,4-Diclorobenzeno foi investigada. Os resultados mostraram sob o 1,4-diclorobenzeno stress, que o crescimento da soja (Glycine $\boldsymbol{m a x}$ ) de raiz de mudas e caule foram inibidas, $L-I$ D-cisteína desulfhydrase (LCD / DCD) atividades enzimáticas foram empossados, em seguida, H2S endógeno aumentado.
Quando aplicado com hidrossulfureto de sódio (NaSH), um doador de H2S, raiz de plântulas de soja, a inibição do crescimento pode ser melhorada. Tratamentos prévios com 0,4mmol $L^{-1} \mathrm{NaHS}$, malondialdeido (MDA) e espécies de oxigênio reactivas conteúdo (ROS) foi reduzida, em seguida, a toxicidade celular da raiz foi reduzida significativamente. Outros experimentos confirmaram que NaSH melhorou a peroxidase de plântulas de soja (POD), superóxido dismutase (SOD) atividades enzimáticas. Em contraste, estes efeitos foram revertidos por hypotaurine (HT), um eliminador de H2S. Então H2S pode aliviar toxicidade 1,4-diclorobenzeno em plântulas de soja por meio da regulamentação das atividades de enzimas antioxidantes para manter a integridade da estrutura celular.

Palavras-chave: sulfeto de hidrogênio $\left(\mathrm{H}_{2} \mathrm{~S}\right)$, das plântulas de soja, 1,4-diclorobenzeno, toxicidade, estresse oxidativo.

\section{INTRODUCTION}

Hydrogen sulfide $\left(\mathrm{H}_{2} \mathrm{~S}\right)$ has been recently discovered to act as a gaseous transmitter. It is therefore the third discovered gaseous signaling molecule, following the discoveries of Nitric oxide (NO) and Carbon monoxide (CO). In plants, $\mathrm{H}_{2} \mathrm{~S}$ is mainly produced via the L-/D-cysteine desulfhydrase enzymes (LCD/ DCD) and it has been reported to be involved in stress responses to drought, heat, heavy metal and salt during seed germination and seedling growth (ZHANG et al., 2010a; JIN et al., 2011; LAI et al., 2014; LI et al., 2014). Applications of $\mathrm{H}_{2} \mathrm{~S}$ could also significantly improve root morphology, chlorophyll content and photosynthetic activity under $\mathrm{Pb}$ stress (ALI et al., 2014).

\footnotetext{
${ }^{\mathrm{I}}$ College of Chemical Engineering, Kaifeng University, Kaifeng, Henan, 475004, China. E-mail: cjfchengssman@163.com. ${ }^{*}$ Corresponding author.

${ }^{\Pi}$ Department of Biological and Chemical Engineering, Chongqing University of Education, Chongqing, China. 
Chlorobenzene dissolved in an organic solvent is an important raw material and intermediate in the pharmaceutical, leather, dye and other industries, where it is widely used. With the discharge of industrial waste, chlorobenzene, which is nonbiodegradable and can accumulate in the environment, enters in ecosystems in different ways, as polluted air, soil and water, potentially causing lasting harm. For example, the presence of 1,2,4-trichlorobenzene reduced maximum root length, plant height, tillers per hill, shoot and root dry weight in rice plants, as a result of changes in the activity of antioxidant enzymes, reactive oxygen species (ROS), malondialdehyde (MDA) and membrane lipid peroxidation (DING et al., 2014). Chlorobenzene also inhibited maize cell division and seedling growth, and the oxidative stress response increased proportional to the compound's degree of chlorination (MIGUEL et al., 2012).

$\mathrm{H}_{2} \mathrm{~S}$ has been identified to play an important role in diverse physiological processes in plants. However, the relationship between $\mathrm{H}_{2} \mathrm{~S}$ and plant chlorobenzene stress tolerance remains poorly characterized, and whether or not oxidation reactions are involved in the process is not clear. The aim of this study was to provide more evidences for potential mechanisms of $\mathrm{H}_{2}$ S-related mitigation of developmental inhibition caused by the organic pollutant, 1,4-dichlorobenzene (1,4-DCB). Changes in root and stem elongation, MDA and ROS contents, and antioxidant enzyme levels were investigated. The results revealed that the presence of $\mathrm{H}_{2} \mathrm{~S}$ alleviated 1,4-DCB-induced stress in soybean seedlings by restoring oxidation balance.

\section{MATERIALS AND METHODS}

Plant materials, growth conditions and processing methods

Seeds of the soybean (Glycine max) variety Zhong Huang 57 were surface-sterilized with a $10 \mathrm{~min}$ long soak in $5 \% \mathrm{NaOCl}$. After being rinsed with deionized water, the seeds were then soaked in an appropriate amount of deionized water for $24 \mathrm{~h}$ to initiate germination. Uniform seedlings were selected and planted in seedling trays containing treated soil. The soil was purchased from Kaifeng Seed Company and contained at least $28 \%$ total organic matter and $2 \%$ total nitrogen, phosphorus and potassium. Varying concentrations of sodium hydrosulfide ( $\mathrm{NaHS}, \mathrm{H}_{2} \mathrm{~S}$ donor) or hypotaurine (HT, $\mathrm{H}_{2} \mathrm{~S}$ scavenger) solutions were added to the dry soil mix, increasing the total water content to $30 \%$, and 1,4-DCB dissolved in acetone was then added to make up the different treatments, with acetone for the controls. Soybean seedlings were maintained at $25^{\circ} \mathrm{C} \pm 1^{\circ} \mathrm{C}$ with a
$14 \mathrm{~h}$ photoperiod (the light intensity was $200 \mu \mathrm{mol} \mathrm{m}^{-2} \mathrm{~s}^{-1}$ ). One week old seedlings were harvested for analysis.

Endogenous $\mathrm{H}_{2} \mathrm{~S}$ content determination and L-/Dcysteine desulfhydrase activity assay

The methylene blue method was used to determine the $\mathrm{H}_{2} \mathrm{~S}$ content in soybean seedling roots, following ZHANG et al. (2008), while root cysteine desulfhydrase activity was determined using the method of JIN et al. (2011). The activity of L-cysteine desulfhydrase was established using $\mathrm{H}_{2} \mathrm{~S}$ (including L-DTT) release. D-cysteine desulfhydrase enzyme activity was also measured by replacing L-cysteine with D-cysteine and using $\mathrm{pH} 8.0$ Tris- $\mathrm{HCl}$ buffer; otherwise, the steps remained the same. Control and treatment data were expressed as means plus standard errors of three independent experiments.

\section{MDA content determination}

The MDA concentration was calculated using the formula of ZHANG et al. (2011).

Determination of hydrogen $\mathrm{H}_{2} \mathrm{O}_{2}$ content and the rate of $\mathrm{O}_{2}$ - generation

$\mathrm{H}_{2} \mathrm{O}_{2}$ content and the rate of $\mathrm{O}_{2} \cdot$ - generation were determined using assay kits produced by the first branch of the Nanjing Jiancheng Biological Engineering Institute.

\section{Histochemical staining and tissue sections}

Evans Blue dye was used to detect the viability of root tip cells in the soybean seedlings following BAKER \& MOCK's method (1994). A 2-3cm root tip was stained for 10 minutes in a $0.25 \%$ Evans Blue solution at room temperature. After a wash with double distilled water, the root tip was photographed.

\section{Antioxidant enzyme activity assay}

POD activity was measured using the guaiacol method, where a 0.01 change per minute at $A_{470}$ was calculated as one enzyme activity unit (U). CAT activity was determined according to LANG \& ZHU's method (2014). SOD activity was determined using the nitro blue tetrazolium chloride (NBT) photochemical reduction method.

\section{RESULTS AND DISCUSSION}

1,4-DCB inhibited soybean seedlings growth and promoted the synthesis of $\mathrm{H}_{2} \mathrm{~S}$

In order to assess toxicity symptoms in soybean seedlings under chlorobenzene stress, different concentrations $\left(0,4,8,16,24 \mathrm{mM} \mathrm{L}^{-1}\right)$ of $1,4-\mathrm{DCB}$ were 
applied in this study. It was determined that 1,4-DCB significantly inhibited the elongation of soybean seedling roots and stems in a dose-dependent manner, with greater inhibition with increasing 1,4-DCB concentrations. Maximum response occurred at doses of $24 \mathrm{mmol} \mathrm{L}^{-1}$, where the length of seedling roots and stems were $33.3 \%$ and $34.7 \%$, respectively, of controls (Figure 1A, B). In order to investigate whether $\mathrm{H}_{2} \mathrm{~S}$ was associated with this process, endogenous $\mathrm{H}_{2} \mathrm{~S}$ concentrations were measured in soybean seedlings. $\mathrm{H}_{2} \mathrm{~S}$ content increased with 1,4-
DCB concentration; when the 1,4-DCB concentration was between 8 and $24 \mathrm{mmol} \mathrm{kg}^{-1}$, the endogenous $\mathrm{H}_{2} \mathrm{~S}$ content in treated seedlings differed significantly from controls (Figure 1C). Therefore, a concentration of $8 \mathrm{mmol}$ $\mathrm{kg}^{-1}$ 1,4-DCB was selected to induce a stress response for further experiments. $\mathrm{H}_{2} \mathrm{~S}$ was mainly produced from L-/Dcysteine in plants (JIN, et al., 2015). Here, DCD activity increased with the concentration of 1,4-DCB and the activity of LCD was significantly elevated at a 1,4-DCB concentration of $8 \mathrm{mmol} \mathrm{kg}^{-1}$; however, as 1,4-DCB levels

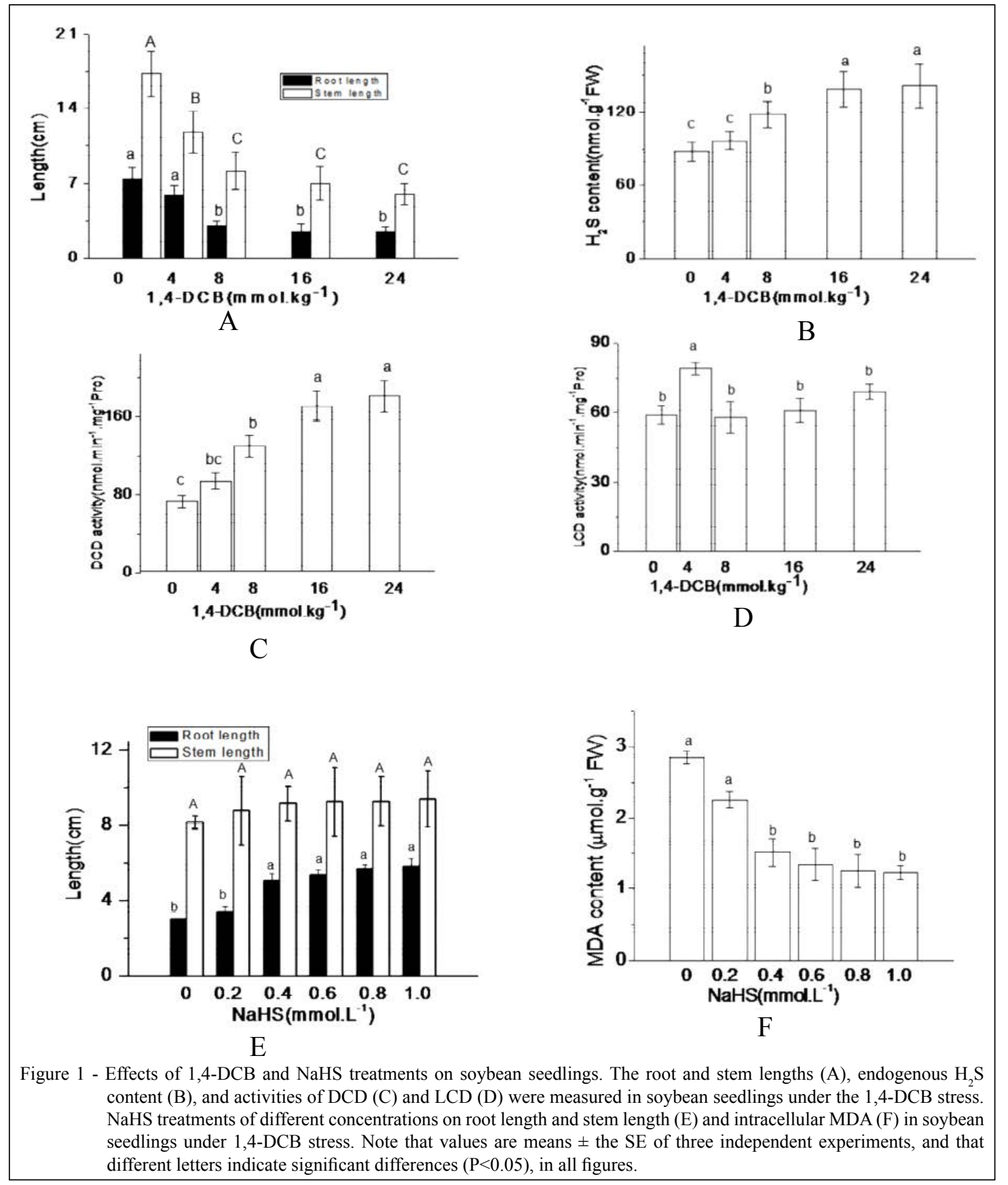

Ciência Rural, v.46, n.10, out, 2016. 
rose above $8 \mathrm{mmol} \mathrm{kg}^{-1}$, the total activity of LCD did not differ from the control (Figure 1D). Thus, these results indicated a possible inter-relationship between LCD/DCDrelated $\mathrm{H}_{2} \mathrm{~S}$ homeostasis and chlorobenzene response in soybean seedlings. The $\mathrm{H}_{2} \mathrm{~S}$ pathway was similar to the generation of $\mathrm{H}_{2} \mathrm{~S}$ in stomatal closure (HOU et al., 2011).

NaHS alleviated 1, 4-DCB-induced toxicity in soybean seedlings

$\mathrm{NaHS}$ has been reported to be $\mathrm{a}_{2} \mathrm{~S}$ donor in previous research (LAI et al., 2014). Therefore, NaHS was applied in this study to examine the effects of $\mathrm{H}_{2} \mathrm{~S}$ on soybean seedlings under 1,4-DCB-induced stress. Experiments were carried out on soybean seedlings planted in soil with different concentrations of $\mathrm{NaHS}$ $\left(0,0.2,0.4,0.6,0.8,1.0 \mathrm{mmol} \mathrm{L}^{-1}\right)$ and $8 \mathrm{mmol} \mathrm{\textrm {kg } ^ { - 1 }}$ 1,4-DCB. Root length inhibition observed under 1,4DCB stress was mitigated progressively as the NaHS concentration increased; this effect might be even further enhanced above $1 \mathrm{mmol} \mathrm{L}^{-1}$ of NaHS. However, there was no detoxification effect of NaHS on stem growth (Figure 1E). This finding agreed with previous results showing that pretreatment with NaHS could improve heat tolerance (LI et al., 2015), but differs from results showing that high concentrations of $\mathrm{NaHS}$ produce toxic effects (LAI et al., 2014). This variation in results might be due to differing physiological concentrations of $\mathrm{H}_{2} \mathrm{~S}$ experienced as a result of variation in the plant material, developmental stage, tissue and organs, and growth environment studied. In addition, this study reported relationship between NaHS concentration and the release characteristics of different $\mathrm{H}_{2} \mathrm{~S}$ donors. Pretreatment with increasing doses of NaHS caused a considerable decrease in the level of 1,4-DCB-induced MDA (Figure 1F). This effect occurred above NaHS concentrations of $0.4 \mathrm{mmol} \mathrm{L}^{-1}$, hence this concentration of NaHS was used in the follow-up experiments.

$\mathrm{H}_{2} \mathrm{~S}$ scavengers aggravated toxic effects of $1,4-\mathrm{DCB}$ in soybean seedlings

In order to clarify the role of endogenous $\mathrm{H}_{2} \mathrm{~S}$ homeostasis in regulating the stress response of soybean seedlings to 1,4-DCB, applications of HT were made in experiments. When HT was applied (at $0.4 \mathrm{mmol} \mathrm{L}^{-1}$ ), soybean seedlings had an opposite phenotype compared to the NaHS treatment. The growth of roots and stems was arrested, and in the presence of both chlorobenzene and HT, this growth inhibition was further aggravated, with root and stem lengths only $26.5 \%$ and $37.4 \%$, respectively, of controls (Figure 2A, B); roots also became thicker. $\mathrm{H}_{2} \mathrm{~S}$ scavengers aggravated the toxic effect of 1,4DCB on cells
$\mathrm{H}_{2} \mathrm{~S}$ reduced the impact of 1,4-DCB stress on plants, mainly by lowering the ROS content, which helped to maintain the integrity of the cell membrane (ZHANG et al., 2015). Under 1,4-DCB stress, pretreatment with HT significantly increased the MDA content (Figure 2C), hydrogen peroxide $\left(\mathrm{H}_{2} \mathrm{O}_{2}\right)$ content and the rate of superoxide radical $\left(\mathrm{O}_{2}^{-}\right)$generation (Figure $2 \mathrm{E})$. This implied that a large number of lipid peroxides were produced, which could eventually damage the cell membrane. In contrast, these effects were reversed by NaHS, indicating that such damage had been alleviated. Similar phenomena have been previously observed; for example, $\mathrm{H}_{2} \mathrm{~S}$ maintained low concentrations of MDA and $\mathrm{H}_{2} \mathrm{O}_{2}$, thereby alleviating aluminum stress (ZHANG et al., 2010b). This effect was confirmed here by using tissue staining. When there was no stress treatment, the root staining was relatively lighter. Under 1,4-DCB stress, pretreatment with HT enhanced the chlorobenzene-related staining pattern, as indicated by a stronger deposition of blue-colored precipitates in root tips (Figure 2D). This result agreed with the effects seen on soybean seedling phenotypes. Hence, the presence of a $\mathrm{H}_{2} \mathrm{~S}$ scavenger, HT, aggravated the toxic effects of 1,4-DCB on cells.

\section{$\mathrm{H}_{2} \mathrm{~S}$ restored redox equilibrium}

To reduce free radical damage to the cell membrane, plants may activate an antioxidant defense system. In this study, soybean seedlings were subjected to 1,4-DCB stress and the activities of different antioxidant enzymes were measured. POD was the most sensitive to the treatment: even at low 1,4-DCB concentrations (4mmol kg ), POD activity increased rapidly. With increasing 1,4-DCB stress, POD activity gradually increased. At the highest concentration of 1,4DCB, POD activity was more than 8 times greater than in the control. As a key regulator of $\mathrm{H}_{2} \mathrm{O}_{2}$, CAT exhibited the opposite trend; as the 1,4-DCB concentration increased, CAT activity decreased. At high 1,4-DCB concentrations, this decline was significant. The activity of SOD, a scavenging superoxide anion, was more stable (Figure 3A). In order to examine the relationship between $\mathrm{H}_{2} \mathrm{~S}$ and antioxidase levels, the $\mathrm{H}_{2} \mathrm{~S}$ inhibitor HT and donor NaHS were applied experimentally. Activities of three kinds of antioxidases were then observed and, as expected, HT acted to further reduce POD and SOD activity. In contrast, NaHS increased the activity of POD and SOD (Figure 3B). The activity levels of CAT, POD and SOD were thus adjusted in soybean seedlings so as to limit the amount of active oxygen species, in order to mitigate the damage from 1,4-DCB. $\mathrm{H}_{2} \mathrm{~S}$ also helped alleviate 1,4-DCB-induced injury by increasing the activity of antioxidant enzymes, maintaining a balance of active oxygen. This finding was consistent with previous 


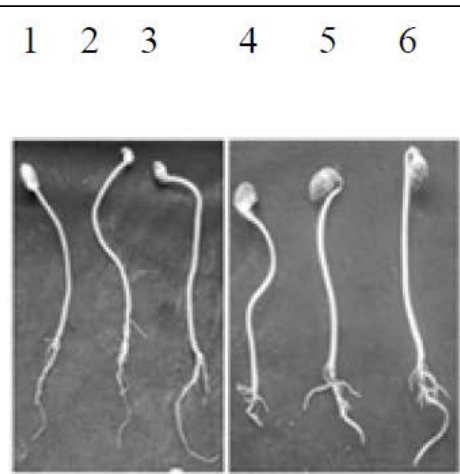

A

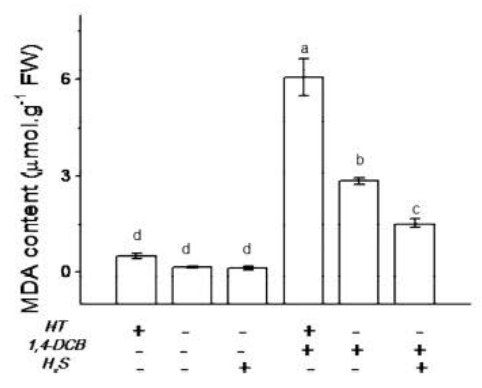

$\mathrm{C}$

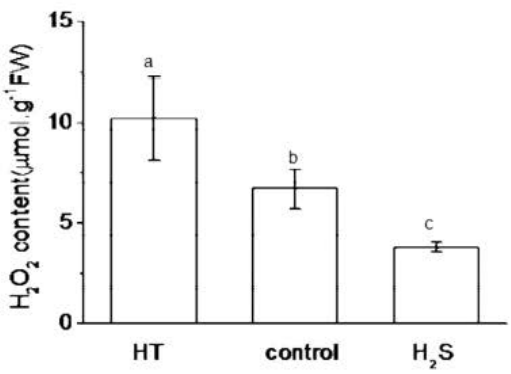

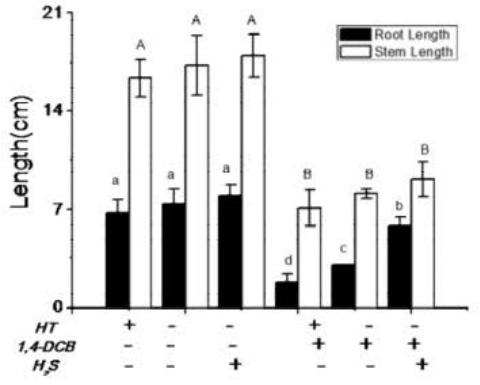

B
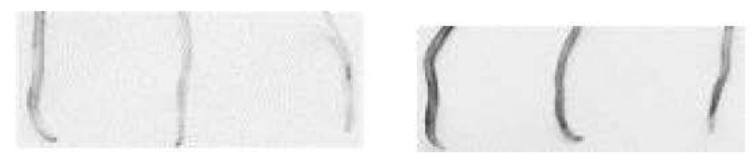

$\mathrm{D}$

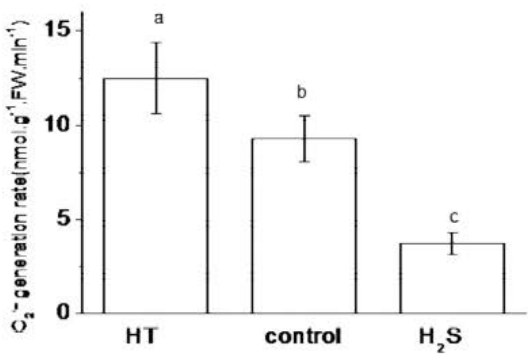

E

Figure 2 - Effects of HT and NaHS treatments on the root length and stem length of soybean seedlings (A \& B), intracellular MDA content $(\mathrm{C}), \mathrm{H}_{2} \mathrm{O}_{2}$ content, and the rate of $\mathrm{O}_{2}^{-}$-generation $(\mathrm{E})$ in soybean seedlings under 1,4-DCB stress. The apical part of treated roots was stained (D).

research in peas that showed $\mathrm{H}_{2} \mathrm{~S}$ increased soluble protein content, as well as the activity of APX, POD and SOD, but decreased CAT activity in root tissues (LI et al., 2010). It was also similar to results, which showed that higher CAT and SOD activity relieved heat and salt stress (LI et al., 2014; LAI et al., 2014). Although the role of antioxidant enzymes in the stress response versus the reaction to $\mathrm{H}_{2} \mathrm{~S}$ was not the same, antioxidant enzymes acted in the cases to maintain stability in levels of oxygen free radicals, keeping their concentration within a low enough range to reduce cellular damage. Results of this study were also consistent with the finding that, through increasing the activity of antioxidant enzymes, plants resisted the effects of aluminum, boron, and tissue hypoxia stresses (WANG et al., 2010., CHEN et al., 2013; CHENG et al., 2013). However, owing to the ubiquity of $\mathrm{H}_{2} \mathrm{~S}$ and its versatile properties, the enhancement of antioxidant capacity to decrease ROS accumulation is 

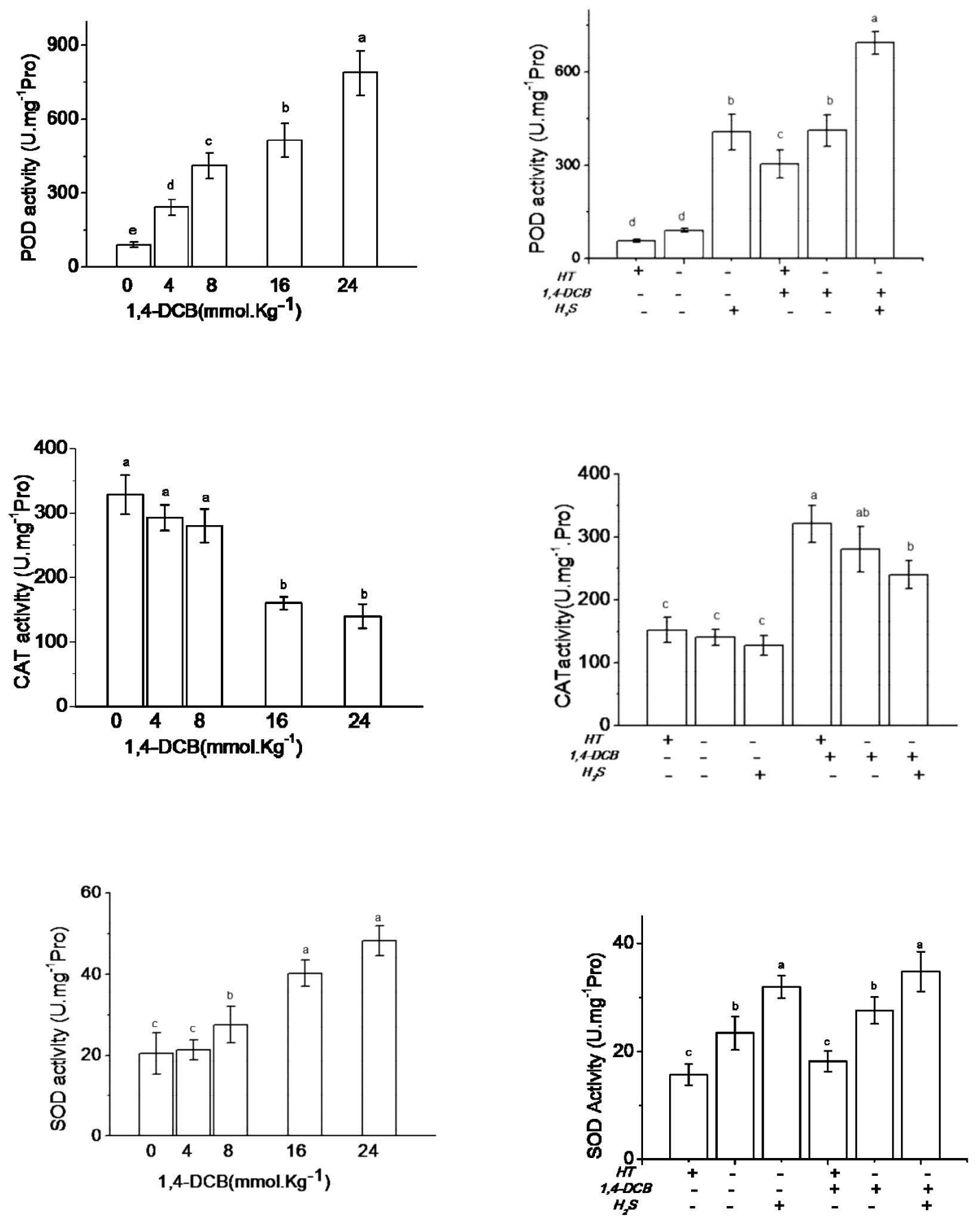

A

$\mathrm{B}$

Figure 3 - Effects of 1,4-DCB (A), HT and NaHS (B) treatments on the activities of antioxidant enzymes in soybean seedlings.

just the first step in the $\mathrm{H}_{2} \mathrm{~S}$-mediated stress response, and the full range of potential molecular mechanisms remain unknown, especially how $\mathrm{H}_{2} \mathrm{~S}$ may interact with other signaling molecules, and so, further research is needed.

\section{CONCLUSION}

This study revealed that the presence of endogenous $\mathrm{H}_{2} \mathrm{~S}$, associated with the total activity of LCD/DCD, effectively improved soybean seedlings' tolerance of 1,4-DCB. Study results further illustrated the role of endogenous $\mathrm{H}_{2} \mathrm{~S}$ homeostasis in the stress 
response, showing that antioxidant activities were changed to block the elevation of ROS.

\section{ACKNOWLEDGMENTS}

This research was supported by Research Fund for Young Backbone Teacher of Higher Education of Henan (2014GGJS-184) and the Key Scientific Research Project of Higher Education of Henan (16B210005).

\section{REFERENCES}

ALI, B. et al. Hydrogen sulfide alleviates lead-induced photosynthetic and ultrastr-uctural changes in oilseed rape. Ecotoxicology and Environmental Safety, v.102, p.25-33, 2014. Available from: $<$ http://www.ncbi.nlm.nih.gov/pubmed/24580818>. Accessed: Feb. 01, 2015. doi:10.1016/j.ecoenv.2014.01.013

BAKER, C.J.; MOCK, N.M. An improved method for monitoring cell death incell suspension and leaf disc assays using Evans blue. Plant Cell Tissue and Organ Culture, v.39, p.7-12, 1994. Available from: <http://rd.springer.com/article/10.1007/BF00037585>. Accessed: Jan. 08, 2014. doi: 10.1007/BF00037585.

CHEN, J. et al. Hydrogen sulfide alleviates aluminum toxicity in barley seedlings. Plant and Soil, v.362, p.301-308, 2013. Available from: $<$ http://link.springer.com/article/10.1007 \%2Fs11104-012-1275-7>. Accessed: Feb. 01, 2014. doi: $10.1007 / \mathrm{s} 11104-012-1275-7$

CHENG, W. et al. Hydrogen sulfide alleviates hypoxia-induced root tip death in Pisum sativum. Plant Physiology and Biochemistry, v.70, p.278-286, 2013. Available from: <http:// www.ncbi.nlm.nih.gov/pubmed/23800663>. Accessed: Apr. 11, 2014. doi: 10.1016/j.plaphy.2013.05.042.

DING, X.W. et al. Effects of 1,2,4-trichlorobenzene on growth and physiological characteristics of rice at maximum tillering stage. Acta Agronomica Sinica, v.40, p.487-496, 2014.

$\mathrm{HOU}$, Z.H. et al. $\mathrm{H}_{2} \mathrm{~S}$ may function downstream of $\mathrm{H}_{2} \mathrm{O}_{2}$ in jasmonic acid-induced stomatal closure in Vicia faba. Chinese Bulletin of Botany, v.46, p.396-406, 2011.

JIN, Z. et al. Hydrogen sulfide improves drought resistance in Arabidopsis thaliana. Biochemical and Biophysical Research Communications, v.414, p.481-486, 2011. Available from: $<\mathrm{http}$ // www.ncbi.nlm.nih.gov/pubmed/21986537>. Accessed: Nov. 21 2015. doi: 10.1016/j.bbrc.2011.09.090.

JIN, Z.P. et al. Physiological implications of hydrogen sulfide in plants: pleasant exploration behind its unpleasant odour. Oxidative Medicine and Cellular Longevity, v.2015, p.1-6, 2015. Available from: <http://dx.doi.org/10.1155/2015/397502>. Accessed: Nov. 10, 2015. doi: 10.1111/j.1742-4658.2005.04567.x.

LANG, J.; ZHU, Y. Comparison of two methods for determination of catalase activity in rice. Journal of the Chinese Cereals and Oils Association, v.29, p.89-99, 2014

LAI, D. et al. Endogenous hydrogen sulfide enhances salt tolerance by coupling the reestablishment of redox homeostasis and preventing salt-induced $\mathrm{K}^{+}$loss in seedlings of Medicago sativa. Plant Science, v.225, p.117-129, 2014. Available from: $<$ http://www.sciencedirect.
com/science/article/pii/S016894521400140X>. Accessed: Jun. 12, 2015. doi: 10.1016/j.plantsci.2014.06.006.

LI, D.B. et al. Effects of exogenous hydrogen sulfide $\left(\mathrm{H}_{2} \mathrm{~S}\right)$ on the root tip and root border cells of PiSum sativum. Chinese Bulletin of Botany, v.45, p.354-362, 2010.

LI, Z.G. et al. Effect of pretreatment with hydrogen sulfide donor sodium hydrosulfide on heat tolerance in relation to antioxidant system in maize (Zea mays) seedlings. Biologia, v.69, p.1001-1009, 2014. Available from: <http://link.springer.com/ article/10.2478/s11756-014-0396-2>. Accessed: Jun. 12, 2015. doi:10.2478/s11756-014-0396-2.

LI, Z.G. et al. Involvement of sulfhydryl compounds and antioxidant enzymes in $\mathrm{H}_{2} \mathrm{~S}$-induced heat tolerance in tobacco (Nicotiana tabacum L.) suspension-cultured cells. In Vitro Cellular and Developmental Biology-Plant, v.51, p.428-437, 2015. Available from: <http://link.springer.com/article/10.1007/ s11627-015-9705-x>. Accessed: Jan. 25, 2016. doi:10.1007/ s11627-015-9705-X

MIGUEL, A.S. et al. Biological responses of maize (Zea mays) plants exposed to chlorobenzenes case study of monochloro,1,4-dichloro and 1,2,4-trichloro-benzenes. Ecotoxicology, v.21, p.315-324, 2012. Available from: $<$ http://link.springer.com/artic le/10.1007\%2Fs10646-011-0792-0>. Accessed: Jan. 12, 2015. doi: $10.1007 / \mathrm{s} 10646-011-0792-0$

WANG, B.L. et al. Boron toxicity is alleviated by hydrogen sulfide in cucum ber (Cucumb sativus L.) seedlings. Planta, v.231, p.1301-1309, 2010. Available from: $<$ http://link.springer. com/article/10.1007\%2Fs00425-010-1134-9>. Accessed: Jun. 12, 2015. doi: 10.1007/s00425-010-1134-9.

ZHANG, H. et al. Hydrogen Sulfide promotes wheat seed germination and alleviates oxidative damage against copper stress. Journal of Integrative PlantBiology, v.50, p.1518-1529, 2008. Available from: <http://onlinelibrary.wiley.com/doi/10.1111/ j.1744-7909.2008.00769.x/>. Accessed: Jun. 12, 2015 . doi: 10.1111/j.1744-7909.2008.00769.x.

ZHANG, H. et al. Hydrogen sulfide acts as a regulator of flower senescence in plants. Postharvest Biology and Technology, v.60, p.251-257, 2011. Available from: <http://www.sciencedirect.com/ science/article/pii/S092552141100007X>. Accessed: Jan. 08, 2014. doi: 10.1016/j.postharvbio.2011.01.006.

ZHANG, H. et al. Hydrogen sulfide alleviated chromium toxicity in wheat. Biologia Plantarum, v. 54, p.743-747, 2010a. Available from: <http://link.springer.com/article/1 0.1007\%2Fs10535-010-0133-9>. Accessed: Jan. 08, 2014. doi:10.1007/s10535-010-0133-9.

ZHANG, H. et al. Hydrogen sulfide alleviates aluminum toxicity in germinatingwheat seedlings. Journal of Integrative Plant Biology, v.52, p.556-567, 2010b. Available from: <http://www. ncbi.nlm.nih.gov/pubmed/20590986>. Accessed: Jan. 08, 2014. doi: 10.1111/j.1744-7909.2010.00946.x.

ZHANG, L. et al. Hydrogen sulfide alleviates cadmium-induced cell death through restraining ROS accumulation in roots of Brassica rapa L. ssp. Pekine-nsis. Oxidative Medicine and Cellular Longevity, v.2015, p.1-11, 2015. Available from: $<\mathrm{http}: / /$ www.hindawi.com/journals/omcl/2015/804603>. Accessed: Jun. 12, 2015. doi: $10.1155 / 2015 / 804603$. 